\title{
Kebijakan Sawit U ni Eropa dan Tantangan bagi Diplomasi Ekonomi Indonesia
}

\author{
Windratmo Suwarno \\ Kementerian Luar Negeri Republik Indonesia \\ J. Taman Pejambon No. 6, J akarta Pusat 10110 \\ ratmo70@gmail.com \\ Diserahkan: 6 Mei 2019; diterima: 17 Agustus 2019
}

\begin{abstract}
Palm oil industry in Indonesia is currently facing a major challenge which began with the European Union Parliamentary Resolution on Palm Oil and Deforestation of Rainforest. Later, the European Commission ratifying the Delegated Regulation No. C (2019) 2055 Final on High and Low ILUC Risk Criteria on Biofuels. It was accused as a form of discrimination against palm oil and contained political motives as well as business competition considering the Indonesia's palm oil products are in accordance with international regulations and sustainable development goals. Therefore, a strategy for palm oil diplomacy is needed to counter this discrimination. For this reasons, Indonesian diplomacy need to provide an explanation to stakeholders in Europen Union and to carry out a regional and multilateral economic diplomacy. This paper will use qualitative methods to describe Indonesia's economic diplomacy in facing the European Union's efforts to reduce palm oil imports.

Keywords: palm oil industry, economic diplomacy, Indonesia-EU relation.
\end{abstract}

\begin{abstract}
Abstrak
Industri sawit Indonesia saat ini sedang menghadapi tantangan besar yang diawali dengan dikeluarkannya Resolusi Parlemen Uni Eropa (UE) mengenai Kelapa Sawit dan Deforestasi Hutan Hujan. Selanjutnya, Komisi Eropa mengesahkan Delegated Regulation No. C (2019) 2055 Final on High and Low ILUC Risk Criteria on Biofuels. Hal ini dipandang sebagai bentuk diskriminasi atas minyak sawit yang mengandung motif politik dan persaingan bisnis mengingat produk minyak sawit Indonesia telah sesuai dengan ketentuan internasional dan tujuan pembangunan keberlanjutan. Karena itu, perlu ada upaya berupa strategi diplomasi sawit untuk menghadapi diskriminasi tersebut. Dalam hal ini diplomasi Indonesia diperlukan untuk memberikan penjelasan pada pihak yang berkepentingan di Uni Eropa dan melaksanakan diplomasi ekonomi secara regional dan multilateral. Tulisan ini akan menggunakan metode kualitatif yang menggambarkan diplomasi ekonomi Indonesia dalam menghadapi upaya Uni Eropa menekan impor minyak sawit.
\end{abstract}

Kata kunci: industri sawit, diplomasi ekonomi, hubungan Indonesia-UE.

\section{PENDAHULUAN}

Sebagai negara produsen sekaligus konsumen kelapa sawit terbesar dunia, industri kelapa sawit telah menjadi bagian penting bagi perekonomian Indonesia. Setidaknya kurang lebih separuh pasokan sawit dunia dipasok dari Indonesia. Berdasarkan data tahun 2007, lahan perkebunan kelapa sawit Indonesia yang memiliki luas sekitar 14,03 juta hektar, mampu menghasilkan sekitar 38,17 juta ton minyak kelapa sawit (Info Sawit, 2018). Dengan volume produksi tersebut, Indonesia memasok sekitar 55\% dari total produksi minyak kelapa sawit dunia yang sebesar
58,9 juta ton. Angka ini menempatkan Indonesia sebagai produsen minyak kelapa sawit terbesar di dunia, mengungguli M alaysia, Thailand, dan Kolombia (Rifai, 2014).

Besarnya industri kelapa sawit Indonesia memiliki peran signifikan dalam menyerap tenaga kerja. Sebanyak 4,2 juta orang merupakan tenaga kerja langsung di sektor kelapa sawit, sementara sekitar 12 juta orang bekerja di sektor-sektor turunan industri kelapa sawit (Angraini, 2018). Kepemilikan perkebunan kelapa sawit tidak hanya didominasi oleh perusahan-perusahaan berskala besar. 
Data statistik menunjukkan $41 \%$ dari total area perkebunan kelapa sawit dimiliki oleh para petani kecil (smallholders) yang jumlahnya berkisar 2,3 juta orang (Erman, 2017). Dengan fakta-fakta tersebut, tidak mengherankan jika kelapa sawit telah berkembang menjadi industri strategis yang bernilai penting bagi perekonomian Indonesia, khususnya di sisi ekspor.

Pada tanggal 4 A pril 2017, industri kelapa sawit Indonesia dikejutkan dengan dikeluarkannya Resolusi Parlemen U ni Eropa (UE) tentang Palm 0 il and D eforestation of Rainforest (minyak kelapa sawit dan deforestasi hutan hujan) (Badan Pengkajian dan Pengembangan Kebijakan-BPPK, 2017). Keluarnya resolusi tersebut menjadi tantangan tersendiri bagi produk kelapa sawit Indonesia, terutama yang akan memasuki pasar U E. Data statistik menyebutkan bahwa U E merupakan tujuan ekspor terbesar kedua Indonesia, setelah India, yang berkontribusi terhadap nilai ekspor kelapa sawitnya. Besaran nilai ekspor kelapa sawit Indonesia pada tahun 2016 merupakan yang terbesar dibandingkan dengan ekspor Indonesia di sektor nonmigas lainnya.

Dengan posisi strategis tersebut, isu ini menjadi perhatian bagi seluruh pihak terkait di Indonesia karena terganggunya ekspor kelapa sawit Indonesia ke U E akan berdampak pada perekonomian Indonesia secara keseluruhan. O leh karena itu, isu kelapa sawit merupakan bagian penting dari upaya diplomasi ekonomi Indonesia yang melibatkan semua pihak. Penelitian ini bertujuan mengetahui upaya-upaya yang dilakukan Indonesia dalam memperjuangkan industri sawit Indonesia, serta menguraikan motif-motif politik dan bisnis yang menjadi akar munculnya resolusi yang bersifat diskriminatif tersebut.

\section{METODE RISET}

Kajian ini dilaksanakan dengan menggunakan pendekatan kualitatif dengan subjek penelitian pernyataanpernyataan oleh Parlemen Eropa terkait masalah sawit Indonesia. Sedangkan, objek penelitian adalah kebijakan dan strategi dalam menghadapi kampanye negatif kelapa sawit yang dilakukan oleh Parlemen U ni Eropa serta tantangan yang akan dihadapi oleh Indonesia terkait dengan masalah kelapa sawit.
Data diperoleh dari penelitian kemudian dikumpulkan, diseleksi, dikategorisasi, diinterpretasi untuk kemudian dijelaskan dan dideskripsikan. Teknik pengumpulan data yang digunakan ialah teknik library research atau penelitian kepustakaan.

Untuk memperkuat deskripsi dan analisis kajian, penulis juga menggunakan data kuantitatif dalam menjelaskan fenomena yang terjadi akibat kampanye negatif atas kelapa sawit di Parlemen Eropa. Dengan demikian, pemahaman atas kampanye negatif dapat dianalisis dengan memperkaya interpretasi atas komoditi kelapa sawit Indonesia serta tantangan terhadap diplomasi ekonomi Indonesia menghadapi kampanye negatif yang dimaksud.

\section{KERANGKA PEMIKIRAN}

Dalam bagian ini akan dijelaskan mengenai pelaksanaan diplomasi ekonomi yang dilakukan, untuk melihat upaya Pemerintah Indonesia dalam menghadapi kampanye negatif minyak sawit oleh UE. Diplomasi ekonomi sangat berhubungan dengan masalah ekonomi yang dihadapi oleh suatu negara dengan negara lain atau entitas lain yang berkaitan dengan ekonomi atau politik suatu negara. Diplomasi ekonomi tidak dapat dipisahkan dari masalah dalam negeri suatu negara dengan yang dipengaruhi oleh berbagai kalangan bisnis atau pelaku usaha.

Bayne dan Woolcock (2007) menjelaskan bahwa dalam diplomasi ekonomi, pemerintah melakukan rekonsiliasi terhadap tiga bentuk ketegangan yaitu (1) ketegangan antara politik dan ekonomi; (2) ketegangan antara tekanan domestik dan internasional; dan (3) ketegangan antara pemerintah dan aktor lainnya, antara lain pelaku bisnis swasta maupun lembaga non pemerintah. M elihat dari bentuk pertama, permasalahan minyak sawit tidak hanya dipersepsikan sebagai isu ekonomi saja namun yang lebih utama adalah masalah politik. Dalam hal ini adalah pengaruh-pengaruh yang dimunculkan melalui kebijakan U E terhadap negara produsen minyak sawit.

Ketegangan dan tekanan internasional akan menekan kondisi domestik suatu negara. Dalam hal ini upaya Parlemen U ni Eropa dalam melakukan kampanye negatif menjadi isu yang sangat memukul kalangan usahawan 
Indonesia khususnya pengusaha kelapa sawit. Kampanye negatif ini semakin hari dapat merusak reputasi tidak saja kondisi ekonomi Indonesia secara khusus tetapi juga reputasi Pemerintah Indonesia dalam mengambil kebijakan terkait dengan masalah lingkungan hidup. Dalam diplomasi ekonomi M aaike 0 kano-H eijmans (2007: 28), menjelaskan bahwa;

E conomic diplomacy involves a 'business end' and a 'powerplay end', and all tools (in mirror view: expressions) of economic diplomacy can be placed somewhere in between these two extremes. W hat is more, the two ends of the spectre can be directly related to the two main determinants of the balance of national interests-that is, economic prosperity on the one hand and political stability and national security on the other hand. This also reflects the idea that economic power involves different forms of power.

Dalam kajian ini, diplomasi melibatkan unsur bisnis perdagangan minyak sawit ke negara-negara di Eropa. Kegiatan diplomasi berujung pada masalah kekuatan dan peran pemerintah dalam mendukung kepentingan nasional ekonomi. M asalah bisnis dan peran pemerintah menjadi penting dalam mendukung kemakmuran ekonomi di satu sisi dan stabilitas nasional di sisi lain. Dalam hal ini, diplomasi ekonomi akan merefleksikan kekuatan ekonomi untuk memajukan kepentingan nasional Indonesia.

\section{PEMBAHASAN}

RESOLUSI SAWIT UNI EROPA

Tanggal 4 A pril 2017, Parlemen U ni Eropa menerbitkan resolusi tentang minyak kelapa sawit dan deforestasi hutan hujan. Tujuan akhirnya adalah melarang impor kelapa sawit yang tidak sesuai dengan pembangunan berkelanjutan serta produk turunannya pada tahun 2020 ke wilayah UE (European Parliament, 2017). Resolusi berjudul Palm 0 il and D eforestation of the Rainforests itu diajukan berdasarkan tudingan bahwa pengembangan industri kelapa sawit menjadi penyebab utama deforestasi dan perubahan iklim. Dalam resolusi yang secara khusus menyebut Indonesia itu, menghasilkan 640 suara dari anggota parlemen yang menyatakan setuju, 18 menolak, dan 28 abstain. R esolusi ini menyoroti beberapa permasalahan yang ditengarai menggelayuti industri kelapa sawit Indonesia dan dalam kurun waktu beberapa tahun terakhir telah menjadi fokus utama negara-negara barat. Selain itu, resolusi tersebut juga mendesak agar minyak kelapa sawit tidak dimasukkan kategori bahan baku dalam program biodiesel UE tahun 2020. Selang dua bulan, pada bulan Juni 2017, Parlemen Norwegia juga menerbitkan resolusi senada yang pada intinya mendesak Pemerintah N orwegia untuk melarang penggunaan maupun pengadaan publik untuk produk minyak kelapa sawit dan seluruh turunannya (BPPK, 2017).

Dalam resolusi yang dikeluarkan oleh Parlemen Eropa mengenai minyak sawit dan deforestasi hutan hujan telah menyatakan pertimbangan umum bahwa;

Recalls that $M$ alaysia and Indonesia are the main producers of palm oil, with an estimated $85-90 \%$ of global production, and welcomes the fact that $M$ alaysian primary forest levels have increased since 1990, but remains concerned that current deforestation levels in Indonesia are running at a rate of $-0,5 \%$ total loss every five years (European Parliament, 2017).

Resolusi ini menunjukkan tindakan diskriminatif terhadap negara penghasil minyak kelapa sawit dan berlawanan dengan posisi UE sebagai champion of open, rules based free, and fair trade (Kementerian Luar N egeri RI, 2017). Data dan informasi terkait perkembangan minyak kelapa sawit dan manajemen kehutanan negara-negara produsen yang digunakan tidak akurat dan akuntabel, termasuk data di Indonesia. Selain itu, resolusi ini juga melalaikan pendekatan multistakeholders dan memuat catatan negatif atas sawit. Di antaranya menyebutkan bahwa sawit merupakan permasalahan serius yang dikaitkan dengan isu korupsi, pekerja anak, pelanggaran HAM, mengesampingkan hak masyarakat adat, sebagai pemicu deforestasi, dan kerusakan habitat. Resolusi tersebut juga merekomendasikan perlunya investasi dari komoditas sawit ke minyak biji bunga matahari dan kanola (Sari, 2017).

U paya untuk menghalangi industri sawit juga dilakukan lewat aturan skim sertifikasi tunggal bagi minyak sawit yang masuk ke UE. Kemudian, secara bertahap UE akan mengeliminasi penggunaan minyak nabati pemicu deforestasi mulai tahun 2020. Resolusi yang dilakukan 
terkait sawit ini tidak terang-terangan menyebut Indonesia, namun seluruh dunia tahu bahwa produsen minyak kelapa sawit terbesar di dunia adalah Indonesia, yang kemudian diikuti oleh M alaysia, Thailand, Kolombia, dan beberapa negara produsen lainnya.

Deforestasi terjadi di hutan lindung sedangkan Tree Cover Loss (TCL) terjadi akibat faktor manusia ataupun karena kebakaran hutan dan bentuk bencana lain. Bahkan menurut data dari World Resources Institute (W RI) terjadi penurunan deforestasi dari tahun 2015 hingga 2016, sesuai data dari Kementerian Lingkungan Hidup dan Kehutanan Republik Indonesia (KLHK) (World Resources Institute, 2017). Dalam hal ini TCL yang terjadi sesuai data $G$ lobal Forest Watch (GFW) memang sebesar 2,422.128 hektar, namun dari data KLHK bahwa telah terjadi penurunan deforestasi di Indonesia sejak tahun 2015 seluas 1,1 juta hektar menjadi 630 ribu hektar. Dalam hal ini terkait sangat bias sekali dan bersifat politis dalam menilai perkembangan kebijakan Indonesia terkait dengan masalah hutan.

Masalah isu deforestasi menjalar menjadi suatu pernyataan dari Komisi Eropa yang menyatakan bahwa "Re calls that Indonesia has recently become the third highest polluter of $\mathrm{C} 02$ in the world and suffersfrom decreasing biodiversity, with several endangered wildlife species on the verge of extinction." D ari hasil studi Komisi Eropa tahun 2013, penyebab deforestasi paling utama adalah sektor pertanian yang mencapai 58 juta hektar, sedangkan sawit hanya menyebabkan 6 juta hektar dari total 239 juta hektar deforestasi. Data ini menempatkan sawit menjadi faktor keempat penyebab deforestasi setelah kedelai dan jagung yang berkontribusi sekitar 2,5\% deforestasi global. Namun demikian, tentu saja kita tidak boleh menutup mata akan laju deforestasi di Indonesia (European Commision, 2013). Sebagian besar deforestasi disebabkan oleh perusahaan perkebunan dan pertambangan besar. Selama rentang waktu 10 (sepuluh) tahun yaitu tahun 2000-2010, perusahaan bertanggung jawab atas sekitar $88 \%$ dari total area yang digunduli, sementara konversi lahan oleh petani hanya menyumbang $11 \%$ (Lee, 2014).

Pertimbangan ini menjadi bias karena Malaysia dan Indonesia telah dituduh sebagai negara sumber utama deforestasi akibat minyak sawit. Parlemen Eropa meskipun menyampaikan apresiasi atas peran Indonesia dan M alaysia dalam mengatasi lingkungn hidup terkait dengan penanaman sawit, namun sudah sekian lama upaya ini justru tidak menghasilkan resolusi untuk membantu masalah lingkungan hidup. Justru sebaliknya, UE melakukan tuduhan deforestasi yang disebabkan atas kelapa sawit. Di samping itu, pernyataan Parlemen Eropa tidak mempertimbangan upaya Pemerintah Indonesia dalam membenahi kawasan hutan hujan. Dalam masalah ini, menurut data dari GFW, bahwa yang terjadi di Indonesia, TCL bukanlah penyebab deforestasi.

\section{TRIALOGUE RED II EUROPEAN UNION}

Proses pengambilan keputusan U E tentang Renewable E nergy $D$ irective (RED) penting bagi produsen minyak sawit karena ada kemungkinan pelarangan biofuel sawit. RED pertama kali diberlakukan pada 25 Juni 2009, dan sejak itu telah menjadi alat pengaturan utama yang digunakan oleh Brussels untuk mengatur penggunaan biofuel. Peraturan ini menetapkan target untuk masing-masing negara anggota mengenai penggunaan energi yang dapat diperbarui dan juga menetapkan kriteria yang memungkinkan biofuel untuk dihitung di bawah target energi yang dapat diperbarui tersebut. M enurut 0 il World, U E adalah produsen biodiesel terbesar di dunia, dengan keluaran mencapai 12,8 M T pada tahun 2017. D iperkirakan bahwa 3,5 M T minyak sawit digunakan sebagai bahan baku (Palm O il Today, 2018).

Pada awal Januari 2018, Parlemen Eropa mengamandemen draf RED untuk memasukkan larangan penggunaan biofuel minyak sawit di Eropa setelah 2021. Langkah ini ditentang keras oleh Malaysia dan Indonesia. Kedua negara menguasai hampir 90\% ekspor minyak sawit global. Sebagai bagian dari rancangan RED yang disetujui oleh anggota Parlemen Eropa, energi terbarukan akan menyumbang setidaknya 35\% dari penggunaan energi keseluruhan UE pada tahun 2030. Bahan bakar nabati yang dibuat dari makanan dan tanaman pangan lainnya akan dikurangi hingga nol pada tahun 2030 di bawah rencana RED Parlemen. U E merupakan pemimpin dalam upaya memitigasi perubahan iklim. Kesepakatan yang telah dicapai dalam revisi RED II UE telah mencakup upaya penurunan sejumlah kategori biofuel tertentu secara 
bertahap dan secara ambisius menggantinya dengan yang dianggap mampu memenuhi target energi terbarukan (Palm O il Today, 2018).

Posisi Parlemen Eropa tentang RED bukanlah kata akhir. Para pemimpin UE kemudian bernegosiasi untuk menyelesaikan draf RED. Negosiasi antaraKomisi Eropa, Parlemen Eropa, dan D ewan U ni Eropa untuk menyetujui teks kompromi RED final ini dikenal sebagai 'trilogue'. A pakah akan melarang biofuel minyak sawit atau tidak, menjadi isu penting dalam negosiasi trilogue. Di sinilah keputusan final akan diambil. Jika kompromi tercapai, keputusan final akan didukung oleh suara di Parlemen Eropa, dan kesepakatan di Dewan. RED baru kemudian akan bergerak maju dan menjadi hukum UE (Palm O il Today, 2018).

Pada tanggal 14 Juni 2018, trilogue telah mencapai kesepakatan politik untuk mengoptimalkan pemanfaatan energi terbarukan di Eropa. Termasuk di dalamnya adalah target energi yang mengikat anggota U E sebesar 32\% pada tahun 2030. Persentase tersebut mungkinan akan ditambah lagi setelah ada tinjauan pada tahun 2023 terhadap persentase awal sebesar 27\% (Palm O il Today, 2018). Kondisi ini memungkinkan Eropa untuk tetap memiliki peran sebagai pemimpin mitigasi perubahan iklim. Seperti tertuang dalam Paris A greement yang menargetkan penurunan pemanasan global hingga $2^{\circ} \mathrm{C}$ sekaligus mewujudkan keseimbangan antara sumber dan rosot gas rumah kaca (sink) dengan cara melakukan transisi keenergi ramah lingkungan berdasar pemerataan, konteks pembangunan berkelanjutan, dan upaya pemberantasan kemiskinan.

Setelah kesepakatan politik dicapai, Parlemen Eropa dan D ewan U ni Eropa diharuskan secara resmi menyetujui teks arahan (directive). Dengan pegesahan oleh dua lembaga legislasi tersebut, beberapa bulan setelahnya, arahan energi terbarukan diperbarui lagi menjadi RED II yang dipublikasikan melalui jurnal resmi U E dan mulai berlaku 20 hari setelahnya. Negara-negara anggota UE harus mengadopsi elemen-elemen baru RED II dan menjadikannya bagian dari undang-undang nasional paling lambat 18 bulan setelah tanggal berlaku.

$\mathrm{H}$ asil kesepakatan trilogue dan minyak sawit berisikan hasil dari negosiasi tiga arah Parlemen Eropa, negara-negara anggota, dan Komisi Eropa untuk mengatur kebijakan energi terbarukan U E di dekadeberikutnya. A rahan energi terbarukan untuk periode 2021-2030 (RED II) memperkenalkan target yang mengikat untuk 'energi terbarukan dalam transportasi' sebesar 14\% dengan bagian maksimum biofuel yang terbuat dari tanaman pangan $7 \%$ dan tindakan tambahan yang bertujuan membatasi penggunaan kelapa sawit. Target pengikatan baru sebesar 14\% untuk energi terbarukan dalam transportasi pada tahun 2030 diperkenalkan, disertai dengan mandat yang dikenakan pada penyedia bahan bakar. Bagian biofuel dalam transportasi di U E adalah 4,2\% pada tahun 2015 (All Africa, 2018).

Negara-negara anggota akan diizinkan untuk mempromosikan bahan bakar nabati yang dibuat dari makanan atau tanaman pangan hingga tahun 2030. M ereka dapat menghitungtarget energi terbarukan hingga tingkat konsumsi 2020 dengan maksimum 7\% dari konsumsi energi final bruto di transportasi jalan dan kereta api. N egara-negara anggota yang memilih untuk membatasi konsumsi bahan bakar nabati berbasis makanan di bawah $7 \%$, dapat mengurangi 14\% transportasi mereka. Anggota menyatakan bahwa saat ini menggunakan makanan atau pakan tanaman dalam transportasi ke tingkat di bawah $2 \%$ akan diizinkan untuk meningkatkan konsumsi mereka hingga maksimal $2 \%$. Teks RED II yang telah disetujui menetapkan kontribusi biofuel, bahan bakar bioliquid, dan bahan bakar biomassa kategori tertentu yang diproduksi dari tanaman pangan dan tanaman pakan, khususnyayang berisiko tinggi terhadap perubahan penggunaan lahan secara tidak langsung (indirect land-use change atau ILU C) dan area produksi yang berekspansi secara signifikan menjadi lahan dengan stok karbon tinggi, akan dibatasi padatingkat konsumsi 2019 (European Parliament, 2018). U ntuk mencapai sasaran energi terbarukan U E, kontribusi dari bahan-bahan kategori tertentu ini akan dihapus (phased out) pada tahun 2030.

Kontribusi biofuel berisiko ILUC rendah akan dibebaskan dari batas-batas tersebut berdasarkan kriteria yang objektif. RED II tidak memberikan perlakuan khusus terhadap salah satu sumber minyak nabati yang meliputi, kanola, biji bunga matahari, kedelai, maupun kelapa sawit. Dalam kesepakatan trilogue, Komisi Eropa ditugaskan 
membuat laporan tentang status perluasan produksi tanaman pangan dan tanaman pakan seluruh dunia selambat-lambatnyatanggal 1 Februari 2019. Komisi Eropa akan memberlakukan D elegated Act dalam menentukan kriteria sertifikasi stok pangan yang area produksinya berekspansi secara signifikan sehingga menghasilkan karbon tinggi.

Diskriminasi sawit UE kemudian berkembang ketika Komisi Eropa mengeluarkan rancangan kebijakan bertajuk D elegated Regulation Supplementing Directive of the EU RenewableE nergy D irectivell yang diajukan oleh Komisi Eropa pada $13 \mathrm{M}$ aret 2019. Komisi Eropa men gesahkan D elegated Regulation N O. C (2019) 2055 Final on H igh and L ow ILUC Risk $C$ riteria on Biofuels. $D$ alam rancangan $D$ elegated Regulation, Komisi Eropa akan menggunakan kriteria ILUC sebagai kriteria bahan minyak nabati yang tinggi sebagai komoditas yang tidak berkelanjutan dan berisiko tinggi. Rancangan ini akan dimuat dalam sebuah jurnal di Eropa dan bila tidak ada negara anggota yang menggugat maka akan disahkan menjadi aturan baku. Penetapan dilakukan oleh Komisi Eropa berdasarkan informasi saintifik mutakhir sebagai komitmen terhadap tindakan anti diskriminasi dalam menyusun laporan dan delegated act (EEAS, 2018).

Teks RED II menetapkan kriteria-kriteria netral dan objektif dalam menentukan kontribusi biofuel terhadap target energi terbarukan untuk negara-negara anggota U E tanpa pemilihan jenis bahan baku tertentu. D engan RED II ini, negara anggota U E bebas mengimpor dan memanfaatkan biofuel serta bahan baku seperti yang dilakukan sebelumnya. Dengan demikian, bersamaan dengan ditetapkannya RED II sebagai undang-undang, ketentuan mengenai biofuel ini akan berkesuaian dengan ketentuan W TO. Komisi Eropa memastikan setiap aturan pelaksanaan akan bersifat adil, seimbang, dan berdasar pada bukti ilmiah kuat dalam rangka memastikan capaian energi terbarukan yang selaras dengan rezim perdagangan internasional (EEAS, 2018).

Aturan dari Komisi Dewan U ni Eropa tersebut tidak adil terhadap minyak nabati lainnya. Kriteria yang akan digunakan dalam ILU C tersebut adalah tahun berdasarkan data deforestasi global 2008-2015 yang sangat terkait dengan tingkat tertinggi deforestasi minyak sawit. Padahal pada tahun 2015, Indonesia mulai mengambil kebijakan untuk membuat aturan atas perkebunan kelapa sawit yang tidak terkendali. Izin untuk penanaman pohon sawit dilakukan setiap tahun pada masa Pemerintahan Susilo Bambang Yudhoyono. Sejak Presiden Jokowi, masalah perkebunan sawit mulai ditertibkan dengan menerapkan moratorium bagi penanaman kelapa sawit (Bisara, 2019).

\section{RESOLUSI SAWIT}

Resolusi mengenai minyak kelapa sawit dan deforestasi hutan hujan disahkan oleh Parlemen Eropa melalui pemungutan suara dalam sesi pleno di Strasbourg pada 4 A pril 2017. D engan berlakunya resolusi ini mencerminkan perlakuan diskriminatif terhadap kelapa sawit dan negara produsennya (Prabowo, 2017). Hal ini berarti juga berlawanan dengan U E sendiri yang berposisi sebagai champion of open, rules based free, and fair trade. Terbitnya resolusi ini mendapat perhatian serius dari Pemerintah Indonesia. $\mathrm{H}$ al ini disebabkan resolusi tersebut berpotensi mengganggu ekspor minyak kelapa sawit I ndonesia keU E, yang merupakan importir terbesar kedua minyak kelapa sawit Indonesia, serta diperkirakan akan berdampak pada perekonomian Indonesia secara keseluruhan, yang pada gilirannya akan berpengaruh pada pencapaian sasaransasaran pada Sustainable D evelopment G oals (SD G s) 2030 (BPPK, 2017).

Sekitar 27 juta ton dari minyak sawit diekspor ke sejumlah negara, sementara sisanya sebesar 6 juta ton dikonsumsi di dalam negeri. Volumeekspor minyak kelapa sawit tersebut berhasil menyumbang pemasukan negara tahun 2016 sebesar U SD 17,8 milyar atau 12,3\% dari total nilai ekspor Indonesia. Sementara di sektor non-migas, jumlah tersebut merupakan 13,6\% dari seluruh ekspor non migas Indonesia. Produk minyak kelapa sawit Indonesia tersebut diekspor ke berbagai negara. D ata tahun 2016 menunjukkan, negara pembeli utama minyak kelapa sawit Indonesia, diurutkan dari jumlah impor terbesar adalah India, UE, China, Pakistan, Timur Tengah, Afrika, dan A merika Serikat. G abungan pengusaha kelapa sawit Indonesia (GAPKI) memperkirakan jumlah permintaan minyak nabati dunia pada tahun 2025 akan meningkat menjadi 226,7 juta ton. Pada tahun 2017, minyak kelapa sawit telah memegang saham sekitar $30,8 \%$ dari total keseluruhan 
minyak nabati yang digunakan dunia (Idris, 2017).

D ari berbagai data-data tersebut dapat dilihat bahwa industri kelapa sawit merupakan industri strategis yang bernilai penting bagi Indonesia, khususnya di sisi ekspor. O leh karena itu, Indonesia berkepentingan untuk terus mengembangkan industri kelapa sawitnya dengan memerhatikan sisi produktivitas, kelestarian lingkungan, dan dampak maksimal terhadap perekonomian negara khususnya para petani kecil, melalui penerapan prinsip-prinsip keberlanjutan (BPPK, 2017). Dalam kaitan ini, pengembangan industri kelapa sawit yang berkelanjutan selaras dengan komitmen Indonesia untuk mencapai sasaransasaran pada Sustainable D evelopment G oals A genda 2030. Efek domino lainnya, yakni resolusi tersebut bisa membuat negara-negara lain melakukan hal serupa pada komoditas andalan ekspor Indonesia tersebut.

$D$ ata dan informasi terkait perkembangan sawit dan manajemen kehutanan di negara-negara produsen yang digunakan untuk menyusun Resolusi Parlemen Eropa pun tidak akurat dan akuntabel, termasuk dalam kasus di Indonesia. Selain itu, resolusi ini juga mengesampingkan pendekatan multistakeholders (Ardhian, 2017). Penyebab utama deforestasi bukanlah berasal dari perkebunan sawit. Kajian Komisi Eropa tahun 2013 menyebutkan dari keseluruhan 239 juta hektar lahan terdeforestasi secara global dalam kurun 20 tahun, sektor peternakan (livestock grazing) menyumbang angka terbanyak, yaitu 58 juta hektar. Sementara 13 juta hektar berasal dari kedelai dan 8 juta hektar berasal dari jagung. H anya sekitar enam juta hektar yang merupakan deforestasi dari sektor minyak sawit. D ari data tersebut, kontribusi sektor kelapa sawit terhadap deforestasi global adalah sebesar 2,5\% saja (European Commision, 2013).

M inyak sawit dapat menjadi bagian dari solusi untuk mengurangi emisi gas rumah kaca dan berkontribusi positif pada peningkatan permintaan global terhadap biofuel sebagai pengganti bahan bakar fosil. M inyak sawit, sampai saat ini, merupakan minyak nabati paling produktif dalam hal perbandingan luas lahan dan hasil produksi. Dibandingkan dengan hasil produksi dari bunga matahari yang sebesar 0,52 ton/ hektar/ tahun dan kedelai 0,45/ ton/ hektar/tahun, produksi dari kelapa sawit dapat mencapai 4,27 ton/ hektar/ tahun. Bahkan produksi kanola masih sangat jauh karena hanya menghasilkan 0,60 ton/ hektar/ tahun (Kementerian Luar Negeri RI, 2017). U sulan skema sertifikasi tunggal dalam Resolusi Parlemen Eropa berpotensi meningkatkan unnecessary barriers to trade dan kontraproduktif terhadap upaya-upaya untuk meningkatkan kualitas keberlanjutan minyak sawit.

Indonesia sendiri sudah mempunyai Indonesia Sustainable Palm 0 il (ISPO ) yang bersifat mandatoris. Kebijakan ini memiliki fokus terhadap perlindungan dan pengelolaan lingkungan. D engan demikian, rekomendasi untuk mengurangi penggunaan minyak sawit secara bertahap (phasing out) seperti tertuang dalam Resolusi Parlemen Eropa dianggap sebagai perilaku proteksionis dan tidak mendasar. Faktanya resolusi tersebut merekomendasikan promosi minyak kanola dan biji bunga matahari yangjustru tidak lebih produktif dan ramah lingkungan bila dibandingkan dengan minyak berasal dari kelapa sawit. Di lain sisi, resolusi tersebut juga mengesampingkan hakhak petani yang bermata pencarian dari ladang sawit. Sekitar 16 juta orang tergantung pada sektor kelapa sawit baik secara langsung maupun tidak langsung. $41 \%$ di antaranya adalah petani-petani kecil di daerah pedesaan. Resolusi tersebut juga mengabaikan upaya keras yang terus dilakukan pemerintah dan multistakeholders Indonesia dalam menjaga dan menyeimbangkan isu pembangunan dan lingkungan hidup, termasuk moratorium ekspansi lahan kelapa sawit, skema kolaboratif antara pemerintahswasta-masyarakat madani untuk restorasi gambut, praktikpraktik manajemen yang berkelanjutan dalam pengelolaan sawit, serta peran Indonesia yang di depan dalam upaya implementasi Paris A greement (Kementerian Luar N egeri $\mathrm{RI}, 2017)$.

\section{INDIKASI POLITIK DALAM RESOLUSI SAWIT}

UE merupakan kawasan yang banyak mengonsumsi minyak nabati. Jenis yang paling banyak dikonsumsi adalah minyak sawit, minyak kedelai, minyak kanola, dan minyak biji bunga matahari. M inyak sawit yang dikonsumsi di U E semuanya diimpor dari negara produsen terutama Indonesia dan M alaysia. Sedangkan, minyak lainnya diiimpor dan dihasilkan sendiri oleh negara-negara di U E. N egaranegara penghasil minyak nabati di Eropa adalah Perancis, Hungaria, Spanyol, Romania, dan Belanda. Perancis dan 
Hungaria terkenal dengan bunga matahari dengan luas 850.000 hektar di wilayah Perancis hingga tahun 1986 dan 317.000 hektar di H ungaria. Sedangkan minyak dari kanola diproduksi oleh Jerman dengan kontribusi $30 \%$, Perancis $26 \%$, dan Polandia 12\%. Namun demikian, jumlah peningkatan produksi masih sangat rendah. Keadaan ini menjadi pemicu adanya faktor politis di balik minyak nabati (Kusumaningtyas, 2017).

M uncul berbagai spekulasi bahwa diskriminasi minyak kelapa sawit yang dilakukan Parlemen Dewan U ni Eropa memiliki kepentingan politik. $\mathrm{H}$ al itu terkait dengan minyak-minyak nabati yang dihasilkan oleh negara-negara di Eropa yang tidak dipersoalkan deforestasinya. Luas areal empat jenis lahan utama penghasil minyak nabati dunia (kelapa sawit, kedelai, biji bunga matahari, dan kanola) tahun 2016 adalah sekitar 200,5 juta hektar. D ari luasan tersebut, 61\% (212 hektar) adalah areal kebun kedelai dan hanya $10 \%$ yang merupakan areal perkebunan kelapa sawit. A kan tetapi, dari segi produksi minyak, dengan luasan lahan tersebut, kedelai hanya mampu menghasilkan 53 juta ton minyak atau sekitar $33 \%$ dari produksi empat minyak nabati yang telah disebutkan sebelumnya. Sebaliknya, 20 juta hektar lahan kelapa sawit mampu menghasilkan 65 juta ton minyak atau $40 \%$ dari produksi empat minyak nabati yang lain (Sawit Indonesia, 2018).

\section{Tabel 1.Perbandingan Produktivitas Minyak B erbagai Tanaman Penghasil Minyak Nabati}

\begin{tabular}{lc}
\hline Jenis Tanaman & $\begin{array}{c}\text { Produktivitas M inyak } \\
\text { (Ton/Ha/Tahun) }\end{array}$ \\
\hline Kelapa Sawit & 4,27 \\
\hline Rapeseed (Kanola) & 0,69 \\
\hline Bunga Matahari & 0,52 \\
\hline Kacang Tanah & 0,45 \\
\hline Kedelai & 0,45 \\
\hline Kelapa & 0,34 \\
\hline Kapas & 0,19 \\
\hline Sumber: Oil World Statistic ISTA Meilke GmBh Hamburg (Oil World, 2008)
\end{tabular}

Produktivitas minyak kelapa sawit per hektar lahan jauh lebih tinggi sekitar delapan sampai sepuluh kali lipat dari produktifitas minyak nabati lainnya. Dalam Tabel 1 dijelaskan bahwa lahan kelapa sawit yang lebih sedikit dapat menghasilkan minyak nabati lebih banyak. Data produktifitas minyak nabati tersebut juga mengungkapkan bahwa perkebunan kelapa sawit paling efisien memanen energi surya menjadi minyak nabati. Berdasarkan data di atas dapat disimpulkan bahwa penggunaan minyak nabati negara-negara Eropa seperti kanola, bunga matahari, kacang tanah, kedelai, kelapa, dan kapas membutuhkan lahan yanglebih luas, tetapi hanya menghasilkan produksi lebih sedikit apabila dibandingkan dengan kelapa sawit. Sebaliknya, kelapa sawit dengan luasan lahan yang sama, bahkan lebih sedikit, mampu menghasilkan produksi lebih besar.

Selain minyak nabati, keluarnya Resolusi Parlemen Dewan U ni Eropa yang menyatakan produk sawit penyebab deforestasi, menciptakan pelanggaran HAM, dan tidak mendukungkeberlanjutan hanyalah dorongan dari pelaku bisnis di Eropa. Sebab, produk sawit Indonesia dianggap mengancam keberadaan bisnis minyak zaitun. M inyak zaitun (olive oil) dan minyak yang berasal dari biji bunga matahari sangat populer dan banyak diproduksi di Eropa. Dampaknya, jika produk sawit masuk keEropa, maka dua jenis minyak yang populer di benua tersebut akan tergerus (Julianto, 2017).

Keadaan ini membuat UE justru semakin dilema terhadap impor minyak sawit dari Indonesia. Kebutuhan terhadap minyak sawit semakin hari semakin meningkat di Eropa, sedangkan lahan yang tersedia sangat terbatas. $\mathrm{Hal}$ ini menyebabkan kebutuhan terhadap minyak sawit tidak bisa digantikan dengan minyak lainnya. Meskipun demikian, U E tetap mempertahankan diskriminasi terhadap minyak sawit dengan berupaya menghentikan penggunaannya untuk bahan baku biofuel.

\section{UPAYA DIPLOMASI INDONESIA}

Pada awal tahun 2015, dalam rapat kerja para kepala perwakilan RI di kementerian luar negeri, Presiden Joko Widodo memberikan instruksi dan mandat kepada kementerian luar negeri untuk melaksanakan diplomasi ekonomi. Paradiplomat harus memiliki pandangan sebagai marketer atau pencari pasar bagi produk-produk Indonesia. Dengan ditetapkannya diplomasi ekonomi sebagai salah satu prioritas Kementerian Luar Negeri RI, sinergi dan koordinasi dengan semua pemangku kepentingan serta merta ditingkatkan dan diperkuat. U paya-upaya yang dilakukan oleh Badan Pengkajian dan Pengembangan Kebijakan (BPPK) Kementerian Luar Negeri RI dalam 
diplomasi ekonomi, khususnya di sektor penguatan industri kelapa sawit yang berkelanjutan ini, lebih mengarah pada pengembangan kerja sama yang intensif dengan kalangan akademisi, peneliti, lembaga thinktank, dan institusi lain terkait, baik dalam dan luar negeri. BPPK diharapkan dapat merumuskan kebijakan luar negeri yang tepat guna dan menjadi bagian penyusunan narasi tunggal kebijakan kelapa sawit berkelanjutan Indonesia (BPPK, 2017).

Kemudian BPPK Kementerian Luar N egeri Indonesia menyelenggarakan forum kajian kebijakan luar negeri (FKKLN) berjudul "Strategi Menghadapi Kampanye Negatif Sawit Indonesia di Eropa dan Amerika," pada tanggal 20 Juli 2017 di Bogor. Penyelenggaraan FKKLN ini bertujuan untuk menghadapi meningkatnya kampanye negatif terhadap kelapa sawit Indonesia di luar negeri, khususnya A merika dan Eropa, terutama dengan dikeluarkannya Resolusi U ni Eropa atas minyak kelapa sawit dan deforestasi pada A pril 2017. D ari hasil beberapa kajian dan diskusi sebelumnya, diidentifikasi isu-isu yang digunakan pihak A merika dan Eropa dalam menghambat ekspor kelapa sawit Indonesia, antara lain adalah isu deforestasi dan lingkungan hidup, kesehatan, dan HAM (pekerja anak dan perempuan). Dari hasil diskusi pada FKKLN ini, para narasumber menyepakati sejumlah strategi untuk diterapkan Pemerintah Indonesia dalam menghadapi kampanye negatif terhadap kelapa sawit Indonesia. Di antara gagasan yang muncul adalah perlunya narasi tunggal bagi perwakilan Indonesia di luar negeri serta lebih mengoptimalkan kerja sama riset antarlembaga penelitian di Indonesia dan negara mitra di kawasan A merika dan Eropa, serta melibatkan semua pemangku kepentingan dalam riset (BPPK, 2017).

Pada perkembangannya, BPPK mengembangkan kerja sama dengan para peneliti dari Collaborative Research C enter 990 (CRC 990), sebuah konsorium penelitian antara Indonesia dan Jerman yang beranggotakan empat perguruan tinggi dari kedua negara, yaitu U niversity of Gottigen, Institut Pertanian Bogor (IPB), U niversitas Jambi (U NJA ), dan U niversitas Tadulako (U NTAD) Palu. CRC 990 telah melakukan penelitian di Jambi, Indonesia, sejak tahun 2012 dengan tema "E cological and Socioeconomic Functions of Tropical Lowland Rainforest Transformation System" (Sumatra, Indonesia) atau disingkat EFForTS. Penelitian
CRC 990 dibagi ke dalam tiga topik utama, yaitu: (1) enviromental process; (2) biodiversity; dan (3) human aspect/ socio economy. Ketiga topik penelitian ini memiliki kaitan erat dengan sejumlah prinsip-prinsip kelapa sawit yang berkelanjutan. Selama jangka waktu lima tahun tersebut, CRC 990 telah menghasilkan lebih dari 60 artikel yang diterbitkan dalam sejumlah jurnal ilmiah internasional (BPPK, 2017).

Selain itu, Indonesia mengupayakan kerja sama diplomasi dengan beberapa negara khususnya negara produsen kelapa sawit seperti Malaysia, Thailand, Kolombia, dan negara-negara lain serta berkerja sama dengan sejumlah organisasi internasional. Seperti halnya kerja sama yang dilakukan dengan Malaysia melalui promosi dalam menghadapi kampanye hitam yang saat ini tengah didengungkan di Eropa, terhadap komoditas itu. Sejauh ini, Jakarta dan Kuala Lumpur telah memiliki mekanisme kerja samakel apa sawit dal am instrumen C ouncil of Palm 0 il Producer $C$ ountries (C PO PC). Presiden Jokowi juga mengajak Thailand untuk bergabung pada CPO PC tersebut (Suastha, 2017). Kerja sama perdagangan di kawasan negara-negara Indonesia, Malaysia, ThailandGroeth Triangle (IMT-GT) memiliki potensi yang besar mencapai 416 miliar dolar AS atau 18,3 persen dari total perdagangan di sekitar Asia Tenggara (ASEAN) adalah $6,9 \%$. Karena itu, Indonesia mengajak negara tersebut untuk kerja sama terkait penjualan sawit (Sutrisno, 2017).

Indonesia dalam kerangka ASEAN berhasil mengedepankan masalah minyak sawit di U E. M asalah minyak sawit sudah menjadi isu dalam diplomasi regional ASEAN. Dalam pernyataan Ketua Konferensi Tingkat Tinggi ASEAN pada 29 A pril 2017, masalah minyak Sawit telah menjadi perhatian serius bagi negara-negara anggota ASEAN . Dalam pernyataaannya disampaikan;

We noted the concern expressed over the adoption of the Resolution on Palm $O$ il and $D$ eforestation of Rainforest by the $E$ uropean Parliament on 4 A pril 2017 which discriminates against oil palm cultivation by singling it out as being the largest contributor to deforestation, to the detriment of the palm oil indus tries in the region. We urged the E uropean U nion to recognize the certification of the Sustainable Palm 0 il Schemes in the countries concerned which is a manifestation of our commitment to the U N Sustainable D evelopment G oals (A SEA N, 2017). 
Pernyataan ini merupakan bentuk keberhasilan bagi diplomasi Indonesia di tingkat regional bahwa negaranegara anggota merasakan keprihatinan yang sangat besar terhadap resolusi minyak sawit. Tindakan yang dilakukan oleh U E merupakan bentuk diskriminasi terhadap minyak sawit dengan menganggap kelapa sawit sebagai penentu kerusakan hutan. Lebih dari itu, upaya U E ini akan secara langsung dapat merugikan masyarakat industri minyak kelapa sawit. Dalam kaitan ini, bentuk diskriminasi yang semakin nyata disampaikan dalam pernyataan tersebut. Padahal secara implisit hanya minyak sawit yang memiliki sertifikat skema berkelanjutan dan memiliki komitmen pada tujuan pembangunan yang berkelanjutan dari Perserikatan Bangsa-bangsa, tetapi justru tidak diakui oleh negara-negara di UE.

Komitmen Indonesiajugatelah ditangkap oleh perdana menteri Malaysia bahwa masalah minyak sawit menjadi isu utama bagi ASEAN. Dalam hal ini Presiden Joko W idodo dan Perdana M enteri M ahatir M uhammad telah menyampaikan surat bersamakepada U E dan menyatakan kekecewaan yang mendalam atas rencana UE untuk melarang penggunaan bahan bakar minyak sawit untuk biofuel (Jakarta Post, 2019). Pernyataan kedua kepalanegara ini merupakan respons dari diplomasi ekonomi yangakan terus berlanjut terhadap kebijakan Komisi U ni Eropa dan bahkan terhadap U E.

N egosiasi dengan UE dalam bentuk persetujuan mitra ekonomi komprehensif pernah dilakukan penundaan negosiasi. Penundaan ini merupakan bagian dari upaya untuk mendesak UE atas proposalnya membatasi biofuel berbasis minyak sawit. Dalam putaran ketujuh negosiasi Indonesia dengan U E dalam Comprehensive E conomic Partnership A greement sempat mengalami penundaan atas desakan Indonesia. Dari negosiasi ini maka duta besar U E di Jakarta (Jakarta Post, 2019) menyampaikan bahwa “...EU renewable energy directive was flexible and the union would be ready to help Indonesia to have its palm oil products meet sustainable development standards. H e said the directive could be revised in 2021 or 2023. Langkah diplomasi ini merupakan salah satu kebijakan untuk melindungi kepentingan nasional di bidang perdagangan.

Di kancah perdagangan internasional, diplomasi ekonomi ditujukan untuk memperjuangkan ekspor produk turunan sawit di World Trade 0 rganization (W TO) di tahapan tinggi yaitu forum A pellate B ody (AB) W TO, yang berfokus pada satu-kesatuan karena mempunyai arti penting khususnya bagi metodologi penentuan normal value untuk harga ekspor dan harga domestik bagi produsen atau pengekspor yang memiliki afiliasi di luar negeri. Setiap negara memiliki hak mengajukan gugatan atas ketidakadilan dalam perdagangan internasional (Rodrik, 2009). Produk kimia seperti certain fatty alcohols merupakan produk kimia turunan dari minyak nabati (sawit). C ertain fatty alcohols dapat digunakan sebagai bahan dasar utama surfaktan untuk kebutuhan detergen, produk perawatan tubuh, dan kosmetik. Indonesia keberatan terhadap putusan panel Dispute Settlement Body (DSB) yang memenangkan U E atas penerapan A rticle 2.3 dan 2.4, serta A rticle 3.1 dan 3.5 A nti-D umping A greement (ADA). Indonesia hanya memenangkan klaim terkait article 6.7 ADA mengenai transparency of investigation report. Putusan panel tersebut menghasilkan posisi 2:1 untuk UE yang tidak menguntungkan bagi Indonesia (Info Sawit, 2017).

Namun, dalam upaya lain, Indonesia memenangkan gugatan yang diajukan terhadap UE di WTO atas pengenaan Bea Masuk Anti Dumping (BMAD) produk biodiesel asal Indonesia. Hasil akhir putusan panel DSBW TO memenangkan enam gugatan Indonesia atas UE. Dengan kemenangan ini, kini akses pasar biodiesel semakin lebar dan bisa kembali memulihkan ekspor biodiesel ke UE. Pasalnya, setelah BMAD ditetapkan sebesar 8,8 persen hingga 23,3 persen pada 2013 silam, ekspor biodiesel Indonesia ke Eropa melorot tajam (Info Sawit, 2017).

Demi menyelesaikan sengketa BMAD biodiesel dan sengketa di DSB-W TO, Indonesia sebelumnya memutuskan menempuh jalur hukum, melalui pengadilan UE. Terdapat tujuh klaim gugatan utama yang ditujukan pada U E. Tak hanya itu, pada M aret 2017, pembelaan Indonesia kembali disampaikan dalam sidang First Substantive M eeting (FSM) dan dilanjutkan dalam sidang Second Substantive M eeting empat bulan setelahnya. A khirnya, panel DSB-W TO telah melihat bahwa UE tidak konsisten terhadap peraturan perjanjian Anti D umping W TO selama proses penyelidikan dumping hingga penetapan BMAD atas impor biodiesel dari Indonesia. Ternyata, enam 
ketentuan perjanjian Anti Dumping W TO telah dilanggar UE dalam sengketa Indonesia mengenai pengenaan BMAD biodiesel. Pertama, U E tidak menggunakan data yang disampaikan pengekspor asal Indonesia dalam menghitung biaya produksi. Kedua, U E tidak menggunakan data biaya-biaya yang terjadi di Indonesia pada penentuan nilai standar sebagai dasar penghitungan batas dumping. Ketiga, UE menentukan batas keuntungan yang terlalu tinggi untuk industri biodiesel di Indonesia. Keempat, metode penentuan tarif ekspor pada salah satu pengekspor Indonesia tidak sesuai ketentuan. Kelima, U E menerapkan pajak lebih tinggi dibanding batas dumping yang seharusnya. Terakhir, U E tidak dapat membuktikan bahwa impor biodiesel dari Indonesia mempunyai efek kerugian terhadap harga biodiesel yang ada di pasaran domestiknya (Gumelar, 2017).

\section{KESIMPULAN}

Keluarnya Resolusi Parlemen U E dan keputusan Komisi UE menjadi tantangan bagi industri sawit di Indonesia. Karena berpotensi mengganggu jalannya perekonomian dan berdampak buruk terhadap berbagai sektor terutama industri dan tenaga kerja. Resolusi ini juga akan mengganggu ekspor minyak kelapa sawit Indonesia ke UE yang merupakan importir minyak kelapa sawit terbesar kedua. Resolusi sawit ini dianggap sebagai bentuk diskriminasi dan memiliki motif politik dilihat dari ketimpangan atas kebijakan yang dihasilkan.

Berdasarkan data dan fakta yang ada, minyak nabati negara-negara UE membuat deforestasi meluas namun menghasilkan volume produksi sedikit. Berbanding terbalik dengan sawit yang menggunakan lahan lebih sedikit tetapi menghasilkan volume produksi yang lebih besar. Dari hal itu, terlihat jelas sekali motif politik dan bisnis UE yang takut bersaing dengan sawit Indonesia. Oleh karena itu, Indonesia melakukan berbagai upaya menyelamatkan industri sawit Indonesia. $\mathrm{H}$ al itu tentu saja dilakukan dengan mengadakan berbagai bentuk kerja sama baik itu negara-negara produsen sawit dan juga negaranegara di Eropa itu sendiri. Langkah diplomasi ekonomi melalui pola regional dan multilateral berhasil dilakukan, namun langkah menuju penyelesaian perang dagang dilakukan melalui W TO yang kemudian dimenangkan oleh Indonesia. U paya diplomasi ini ternyata berhasil menekan UE untuk mulai mempertimbangkan kembali penghapusan minyak bagi bahan biofuel.

\section{REFERENSI}

All Africa. (2017). New EU Biofuel Rules Not Enough to Help People or the Planet. Dipetik Agustus 17, 2019, dari https:// allafrica.com/stories/201806140456.html

Angraini, K. (2018, November 2). Bappenas: Industri Kelapa Sawit Serap 16,2 Juta Tenaga Kerja. Dipetik Agustus 6, 2019, dari https://bisnis.tempo.co/read/1142496/bappenas-industrikelapa-sawit-serap-162-juta-tenaga-kerja/full\&view=ok

Ardhian, M. (2017, April 10). Mendag Curigai Kepentingan Bisnis di Balik Resolusi Sawit Eropa. Dipetik Juli 9, 2019, dari https:// katadata.co.id/berita/2017/04/10/mendag-curigai-kepentinganbisnis-di-balik-resolusi-sawit-eropa

ASEAN. (2017, A pril 29). Chairman's Statement 30th Asean Summit Manila: Partnering For Change, Engaging The World. Dipetik Agustus 7, 2019, dari https://asean.org/storage/2017/ 04/Chairs-Statement-of-30th-ASEAN-Summit_FINAL.pdf

Badan Pengkajian dan Pengembangan Kebijakan-BPPK. (2017). Diplomasi Sawit. Diambil kembali dari Kementerian Luar Negeri.

Basara, D. (2019, April 9). Jokowi, Mahathir Tell Brussels to Get Ready for Retaliation Over Discriminatory Palm Oil Restriction. Diambil kembali dari Jakarta Globe: https://jakartaglobe.id/ context/jokowi-mahathir-tell-brussels-to-get-ready-forretaliation-over-discriminatory-palm-oilrestriction/

Bayne, N., \& Woolcock, S. (2007). The New Economic Diplomacy: Decision-Making and Negotiation in International Economic Relations. Aldershot: Ashgate.

Erman, E. (2017). Di Balik Keberlanjutan Sawit: Aktor, Aliansi Dalam Ekonomi Politik Sertifikasi Uni Eropa. Masyarakat Indonesia, 43(1).

European Commision. (2013). The Impact of EU Consumption on Deforestation: Comprehensive Analysis of the Impact of EU Consumption on Deforestation. Diambil kembali dari http:// ec.europa. eu/environment/forests/pdf/ 1.\%20Report\%20analysis\% 20of\%20impact.pdf

European Parliament. (2017, April 4). European Parliament Resolution of 4 April 2017 on Palm Oil and Deforestation of Rainforests. Dipetik Juli 25, 2018, dari http:// www.europarl.europa.eu/sides/ getDoc.do? pubRef=-//EP// TEXT+ TA + P8-TA-2017-0098+0+DOC+XM L+ V0//EN

European Parliament. (2018). Directive (EU) 2018/2001 of The European Parliament And Of The Council, of 11 December 2018. Dipetik Agustus 6, 2019, dari https://eur-lex.europa.eu/ legal-content/EN/TXT/

?uri=uriserv:OJ.L_.2018.328.01.0082.01.ENG\&toc=0):L:2018:328:TOC

European Union. (2018, Juni 25). Palm Oil: Outcome of the Trilogue of the EU's Renewable Energy Directive (RED II). Dipetik Juli 17, 2018, dari https://eeas.europa.eu/delegations/ indonesia/46646 /palm-oil-outcome-trilogue-eu\%E2\%80\%99srenewable-energy-directive-red-ii_en

Gumelar, G. (2017, Mei 9). Resolusi Sawit Uni Eropa Disinyalir 
Karena Persaingan Dagang. Dipetik Juli 4, 2019, dari https:// www.cnnindonesia.com/ekonomi/20170509135906-92213466/ resolusi-sawit-uni-eropa-disinyalir-karena-persaingandagang

Gumelar, G. (2017, Januari 26). RI M emenangkan Gugatan WTO Atas Bea Masuk Biodiesel Uni Eropa. Dipetik Juli 5, 2018, dari https://www.cnnindonesia.com/ekonomi/2018012610371592-271717/ri-memenangkan-gugatan-wto-atas-bea-masukbiodiesel-uni-eropa

Idris, M. (2017, April 18). Ekspor Sawit ke Eropa Dihambat, Apa Dampaknya Bagi RI? Dipetik Juli 4, 2018, dari https:// finance.detik.com/berita-ekonomi-bisnis/d-3477946/eksporsawit-ke-ero pa-dihambat-apa-dampaknya-bagi-ri

Info Sawit. (2017). Indonesia Banding di WTO, Terkait Anti Dumping Certain Fatty Alcohols di Uni Eropa. Dipetik Juli 5, 2018, dari https://www.infosawit.com/news/6529/indonesiabanding-di-wto- terkait-anti-dumping-certain-fatty-alcoholsdi-ue

Info Sawit. (2018, Januari 31). 2017 Produksi M inyak Sawit Indonesia Capai 41,9 Juta Ton. Dipetik Agustus 6, 2019, dari https://www.infosawit.com/news/7672/2017-produksi-minyaksawit-ind onesia-capai-41-9-juta-ton

Jakarta Post. (2019, March 21). Indonesia Reviews CEPA After EU Proposes Cap On Palm Oil-Based Biofuels. Dipetik Agustus 7, 2019, dari https://www.thejakartapost.com/news/2019/03/21/ indonesia-reviews-cepa-after-eu-proposes-cap-on-palm-oilbased-biofuels.html

Jakarta Post. (2019, April 8). Palm Oil Plan. Diambil kembali dari https://www.thejakartapost.com/news /2019/04/08/jokowimahathir-send-letter-of-objection-to-eu-over-palm-oil-plan.html

Julianto, P. A. (2017, M ei 3). Pemerintah Anggap Resolusi Sawit Uni Eropa Bermotif Bisnis. Dipetik Juli 9, 2018, dari https:// ekonomi.kompas.com/read/2017/05/03/100000326/ pemerintah. anggap.resolusi.sawit.uni.eropa.bermotif.bisnis

Kementerian Luar Negeri RI. (2017). Tanggapan atas Resolusi Parlemen Eropa Tentang Minyak Sawit. Diambil kembali dari https://www.kemlu.go.id/id/berita/Pages/Tanggapan-AtasResolusi-Parlemen-Eropa-Tentang-M inyak-Sawit-.aspx

Kusumaningtyas, A. S. (2017). Upaya Hambatan Non-Tarif oleh Uni Eropa terhadap M inyak Sawit Indonesia. Jurnal Hubungan Internasional. Dipetik Juli 21, 2019, dari http:// repository.unair.ac.id/68023/1/Fis.HI.82.17\%20.\%20Kus.u\%20\%20JURNAL.pdf

Lee, J. S. (t.thn.). 2014) Environmental impacts of large-scale oil palm enterprises exceed that of smallholdings in Indonesia. Conservation Letters. 7(1).

Palm Oil Today. (2018, Maret 12). Trilogue Negotiation to Determine Palm Biofuels Ban. Dipetik Juli 18, 2018, dari http:// palmoiltoday.net/trilogue-negotiations-will-the-palm-biofuelsban-prevail/

Policy Analysis and Development Agency. (2018). Palm Oil Diplomacy, Center for American and European Region. Diambil kembali dari Minister of Foreign Affairs of Republic of Indonesia.

Prabowo, E. (2017, Desember 5). Resolusi Sawit Parlemen Eropa yang Merugikan Indonesia. Dipetik Juli 4, 2018, dari https:// ekonomi.kompas.com/read/2017/12/05/155319126/resolusisawit- parlemen-eropa-yang-merugikan-indonesia

Rifai, N. (2014). Dampak Pengembangan Produk Turunan M inyak Sawit terhadap Peningkatan Ekspor Produk Minyak Sawit Ke Pasar Amerika Serikat. Jurnal Agro Ekonomi, 32(2).

Rodrik, D. (2000). What Next for the WTO? The American Prospect, $11(5)$.

Sari, E. V. (2017, April 17). M enteri Perdagangan Berencana Bikin Standar Sertifikat M inyak Sawit. Dipetik Juli 13, 2018, dari https://www.cnnindonesia.com/ ekonomi/ 2017041716375992-208126/mendag-berencana-bikin-standar-sertifikat-minyaksawit

Sawit Indonesia. (2018, Januari 3). Produktivitas Sawit Tinggi Tetapi Efisien Penggunaan Lahan. Dipetik Juli 13, 2018, dari https:// sawitindonesia.com/rubrikasi-majalah/berita-terbaru/ produktivitas-sawit-ting gi-tetapi-efisien-penggunaan-lahan/

Sron, B. (2018, Maret 12). Trilogue Negotiation to Determine Palm Biofuels Ban. Dipetik Juli 17, 2018, dari http://palmoiltoday.net/ trilogue-negotiations-will-the-palm-biofuels-ban-prevail/

Suastha, R. D. (2017, Agustus 12). RI-M alaysia Lawan Resolusi Diskriminatif UE soal Sawit. Diambil kembali dari https:// www.cnnindonesia.com/internasional/20170812031841-106234173/ri-malaysia-lawan-resolusi-diskriminatif-ue-so al-sawit

Sutrisno, D. (2017, April 30). Indonesia Ajak Thailand Lawan Resolusi Sawit Eropa. Dipetik Juli 9, 2018, dari https:// republika.co.id/berita/ekonomi/makro/17/04/30/op7f14382indonesia-ajak-thailand-law an-resolusi-sawit-eropa

Winarto, Y. (2017, Juni 10). RI Banding atas Produk Turunan Sawit di WTO. Dipetik Juli 9, 2018, dari https://industri.kontan.co.id/ news/ri-band ing-atas-produk-turunan-sawit-di-wto

World Resources Institute. (2017, Oktober 23). Technical Blog: Caveats to the 2016 Tree Cover Loss Data, Explained. Dipetik November 5, 2017, dari https://www.wri.org/blog/2017/10/ technical-blog-caveats-2016-tree-cover-loss-data-explained 